\title{
A Comparative Analysis of Emotion and Sentiment Analysis Method from Twitter Text
}

\author{
Dr. S. Lavanya a , Dr. T. Kowsalya ${ }^{\text {b }}$, Dr. J. Preetha ${ }^{\text {c }}$, V. Sharmila ${ }^{\text {d }}$, Dr. P. Rupaezhilarasi ${ }^{\mathrm{e}}$ \\ ${ }^{\mathbf{a}, \mathbf{c}, \mathbf{d}, \mathbf{e}}$ Department of Computer Science and Engineering, \\ Muthayammal Engineering College(Autonomous),Rasipuram,Tamilnadu \\ ${ }^{b}$ Department of Electronics and Communication Engineering, \\ Muthayammal Engineering College(Autonomous),Rasipuram,Tamilnadu
}

Article History: Received: 11 January 2021; Accepted: 27 February 2021; Published online: 5 April 2021

\begin{abstract}
The Study of Sentiment is an area of science that specializes in the analysis of strong emotions expressed in texts. An opinion is a complete perception of a commodity, service, association, individual or some other form of entity about which a given text is conveyed. This work provides valuable knowledge of the roots of sentiment analysis and how sentiment evaluators can be configured. We demonstrated how to construct a basic classifier and use it as an example. These approaches will eventually change and there will still be the need for a more extensive assessment of emotions. Non-textual material has an important significance in analyses. Photos, photographs, animations and other visual material are also useful in performing social research. Of course, I can see that all these hyperlinks provide essential material. Some other ways of using social media are likes, retweets, reviews on posts and much more! It is hoped that common issues such as avoiding irony and sarcasm would be made less ambiguous. However, there will emerge other issues that will have to be tackled.
\end{abstract}

Keywords: Accuracy, Machine Learning, Natural Language Performance, Processing, Sentiments Analysis, Supervised Learning, Twitter.

\section{Introduction}

In any decision-making process, people use the opinions of other individuals to make choices. Asking for help, advice or an opinion is nothing more than a resource that allows a human being to broaden his or her knowledge on a certain subject with the aim of minimizing the risk of making a bad decision [1].

Not long ago, before the advent of the Internet and its current pervasiveness in every aspect of our lives, the main sources of opinion were the knowledge and experience of the people closest to us who were part of our circle of relationships and friends. When it came to buying a TV or renting a movie at a video store, we would choose one option or the other based on the opinion of our friends, family or colleagues. Word of mouth was the system we used to convey opinions, judgments and express the virtues or defects of products and services. At that time, over fifteen years ago, we used other types of resources during the decision-making process. Paper publications specialising in particular subjects advised us when we bought a computer, a car or went on holiday to a remote country. The culture and entertainment section of traditional newspapers served as a loudspeaker to advertise plays, exhibitions or films and allowed us to organise our weekend leisure time[2].

Although traditional sources of opinion have not disappeared, there is no doubt that the implementation of the Internet and especially the arrival of the so-called Web 2.01 have meant a profound change in the way people seek opinions to help them during the decision-making process. The Internet has become an immense ocean where millions of people express their opinion on any subject at any time. It is precisely the bidirectionality referred to in the concept of Web 2.0. that has made it possible for anyone to know instantly the opinion of thousands of users on any issue and also contribute to the debate with their own opinion. It is this way of interacting that makes it possible to create virtual networks where several people related on the basis of a specific topic and at a precise moment can exchange their particular vision about that topic. We have gone from asking for the opinion of our closest circle of relations to seeking the opinion of absolute strangers before making the decision to buy a TV, rent a hotel room, go to the cinema or even vote for a certain political party. The change has been so forceful and effective that there is no longer a website that does not have an opinion section associated with its own publications and where users can express their opinions on the subject to be dealt with, from simple news items to amateur videos published by anonymous people. The immediacy of the information associated with the large number of messages makes the Internet and Web 2.0 an absolute revolution in terms of opinion. [3]. Organizations, companies and even governments are also aware of the importance of these opinions and their value as a tool for improving their products, services and general reputation. What years ago had to be obtained on the basis of long and costly processes of survey analysis can now be achieved without having to invest in this type of study and with greater speed, measuring at each moment the Sentiments of people about a certain subject related to their business or performance.

Once we know the importance of all this information of opinion and Sentiment poured out at every moment on the Internet, we should ask ourselves how we can work with it without getting lost in the vast and extensive sea of opinions and fainting in the attempt. This dynamic challenge of manipulating too much data involves modern technology that are capable of collecting, analysing and reflecting a vast amount of emotion on something. This approach could contribute to the development of a framework that makes Sentiment analysis more convenient and easy to use [7]. 


\section{Natural Language Processing}

Natural Language Processing (NPL) is a field within the area of artificial intelligence, computing and linguistics. Its fundamental objective is to facilitate and make communication between people and computers effective through the use of protocols such as natural languages. These languages are those used by people to communicate with each other both orally and in writing. Communication is an essential element in establishing relationships between individuals or entities, whether they are of the same type or not. It is easy to deduce that communication between elements of the same nature, such as between people, machines or animals of the same species, is simpler, more direct and effective than when it occurs between entities of different origin. For this reason and due to the existing relationship between people and computers, it is necessary to search and study protocols that facilitate communication and interaction between both objects in order to improve their relationships. It is the area of the PLN that is in charge of this task[8]. The history of NLP dates back to the mid20 th century with the emergence of a new discipline within computer science. Its aim was to develop systems that were intelligent enough for communication between people and machines to take place through the use of natural language. At that time, just after the Second World War, the importance of having a system that would allow texts to be translated between different languages automatically was well known. One of the systems created at that time was the so-called Georgetown-IBM Experiment, in 1954. Developed jointly by Georgetown University and IBM, the experiment consisted of a demonstration of automatic translation between the English and Russian languages. It had a set of grammatical rules and a couple of hundred vocabulary elements to carry out the translations. Through a rudimentary interface, a non-Russian-speaking operator entered a series of sentences about politics, science or mathematics that were processed by an IBM 701 computer, generating a printout with the sentences translated into English. Although the milestone that this test represented is indisputable, it is necessary to say that the sentences to be translated were specially chosen for the test. The system did not carry out any kind of syntactic analysis to detect the structure of the sentences and the approach used was based on dictionaries where the words were associated with very specific rules. Even so, the results of the test generated high expectations as the authors stated that the problem of automatic translation would be solved in a few years, making the investment in this type of system skyrocket. More than ten years after that test, researchers in this field recognised that their progress was much slower than expected, so that the funds invested in research were radically reduced[9].

\subsection{Levels of Analysis for NLP}

Any NFP system must carry out a set of language analysis tasks that facilitate understanding between the user and the system itself. These tasks constitute an architecture of levels through which sentences are sequentially analysed and interpreted until they are understood and assimilated by the NLP system[12]. Broadly speaking, there are four main components or levels of analysis, but not all of them need to be implemented. It is the functions to be performed by the system that determine which levels of analysis need to be developed. These components, ranked from least to most complex, are as follows:

- Morphological Analysis Level: In this component, words are examined to extract roots, flexible features, suffixes, prefixes and other elements. It aims to understand how words are constructed from smaller units of meaning called morphemes.

- Syntactic Analysis Level: Analyses the structure of sentences based on the grammatical model used in order to know how words are joined to create sentences.

- Semantic Analysis Level: It provides meaning to sentences and gives them a significance, also resolving lexical and structural ambiguities that may appear.

- Pragmatic Analysis Level: It deals with the analysis of texts beyond that of an isolated sentence, taking into consideration those immediately preceding them, the relationship between them and the context in which they are produced.

Usually, the input text is processed by a technique known as tokenization. This tries to identify the minimum units of information, known as tokens, by dividing sentences into individual words, punctuation marks and other elements. The tokens are treated by each of the components or levels of the architecture until finally the text provided as input is understood by the system: As indicated above, depending on the NFP system to be developed, the implementation of different analysis components will be necessary. For example, for an automatic translation system, the levels of morphological and syntactic analysis are sufficient [13]. On the other hand, a virtual assistant also needs to understand the meaning of the user's commands, so it will be necessary to have semantic and pragmatic analysis components as well.

\subsection{Approach and Method Followed}

The analysis of Sentiments, and especially that which focuses its scope on social networks, is a field of research of recent appearance. The main source of information can be found in the research studies published by universities around the world, which can reach several hundred each year. Together with the popular articles on sentiment analysis that can be consulted on the Internet, this will be the main source of knowledge on which this PAPER will be based. Therefore, the strategy consists of compiling this type of publication using specialised 
academic search engines such as Google Scholar, Springer Link, Dialnet, BASE or the UOC's online library. Subsequently, the studies with the greatest number of citations should be detected and the most important concepts and techniques used to solve the problem of classifying texts based on Sentiment should be extracted from them.

The next step will be to look for tools to build automated classification systems following the indications of the publications consulted, as well as the various examples that already exist on the Internet. In addition, special consideration will be given to the knowledge acquired in the subject of Advanced Artificial Intelligence and the practices carried out with the Python language13 and machine learning libraries such as Scikit-Learn14

\subsection{Motivation}

The field of Artificial Intelligence deals with computer programmes that can identify subtle correlations in data, and generate predictions and assumptions based on those connections. This data will offer countless insight into future problems faced by people and social classes on the planet. As developments unfold, the massive deployment of automatic learning technologies would make it easier to meet goals that would seem like science fiction in the future.

\section{Background Analysis \& Review}

Sentiment level analysis is probably the one to which a greater percentage of the studies published each year on this area of research are devoted and its main objective is to classify a document based on the Sentiment it expresses. This task is also known as classification of Sentiments in documents. Documents are considered the basic units of information and these can be opinions in blogs, online shops, specialised websites or messages in social networks. The opinion generally takes a value from among three possible ones: positive, negative or neutral Sentiment, although, as we will see below, there are also other scales and these can also be numerical, continuous or discrete.Taking as a starting point the formal definition of opinion described in previous sections, the classification of sentiment at document level can be represented by the following fivefold:

( , GENERAL, s, , )

Thus, given sentiment, this level of analysis tries to determine the Sentiment $\mathrm{s}$ of the GENERAL aspect of the entity e. Entity e, the author of opinion $\mathrm{h}$ and the time when it was issued $\mathrm{t}$ are known or irrelevant. The value $\mathrm{s}$ can be one of several categories available (e.g. positive, negative or neutral) or a numerical value (e.g. a value between 1 and 5). The first case is known as classification while the second is called regression.In order to ensure that this classification process can be carried out, it is necessary to assume that the document to be classified expresses an opinion about a single entity and that this opinion belongs to a single person. Therefore, if a text expresses opinions on different entities, their assessments or Sentiments could be different from each other, which would prevent the classification of the global document in a single category. The same is true if several people express their opinion in that text. In this case, it is possible that their opinions are different so the classification process would fail for the same reason as the previous example. In any case, this type of sentiment analysis is appropriate for product and service reviews and can also be applied to social media messages. In all cases and in general, the text is written by a single person and usually deals with a single topic or entity.

\subsection{Methods for the Classification of Documents}

To carry out the classification of a document based on its sentiment, there are various methods and techniques that are being refined and improved as research on this subject advances and new studies and works appear on the scene. Despite the multitude of articles and publications presented each year, an issue that shows a current of research in full swing and growth, there does not seem to be a clear consensus on which techniques should be used to obtain the best results in the process of classifying texts. And it is because of this large number of publications and a field of research that is undergoing a process of strong expansion that it is not easy to establish a clear division of the methods that currently exist. Even so, several authors such as [17] or[18] establish two main groups, supervised and unsupervised methods and the latter in turn based on dictionaries or linguistic relations.

\section{Proposed Work}

This section will present a method for solving the problem of classifying texts by their sentiment at document level. These sentiment will be messages that have been published on the social network Twitter and the chosen method will be based on supervised learning algorithms. For this, it will be necessary to have a training corpus whose examples must have been previously labelled with the category of the Sentiment to which they belong. In this section several algorithms will be trained using different techniques and the necessary steps to create the models will be detailed. From all the possible combinations, the best one will be chosen based on a series of measures widely used to evaluate this type of system.

\subsection{Sentimental Analysis on Twitter}

There are two main groups of methods for solving the problem of sentiment classification: supervised methods and unsupervised methods. In this paper a supervised solution will be shown, based on automatic learning algorithms and trained through a corpus formed by thousands of tweets manually classified by a group of people. This test is divided into two parts. In the first one, the effectiveness of several algorithms trained with the messages of the corpus will be tested and on which different standardization techniques, feature extraction and 
weighting methods will have been applied. The best combination, the baseline 21 classifier, will move to a second phase to try to improve the results of the model through new feature extraction techniques. The following sections will present the message corpus and the four self-learning algorithms selected for this practice, as well as the metrics to be used to objectively determine the best configured classifiers. We will close this section with the conclusions drawn from these experiments. On a technical level, it should be noted that the models will be written in Python22 and specific libraries will be used for this type of development, such as NLTK23, which specialises in language processing and Scikit-Learn24, which offers resources for the implementation of automatic learning systems.

The messages in the corpus are classified into four and six categories of Sentiment: Very positive $(\mathrm{P}+)$, Positive $(\mathrm{P})$, Neutral (NEU), Negative $(\mathrm{N})$, Very negative $(\mathrm{N}+)$ and No Sentiment (NONE). From these six categories and by unifying the messages divided by their intensity into unique groups, the classification system based on four classes is obtained: Positive (P), Neutral (NEU), Negative and No Sentiment (NONE). This will be the classification on which the TFM tests will be based. Before continuing, it is necessary to explain the difference between messages without Sentiment (NONE) and neutral messages (NEU). The former are precisely that, tweets in which no positive or negative idea is expressed. For example:

“ABC7 News@abc7newsbayarea Sep 7, 2020

THIS JUST IN: Fire officials say "a smoke generating pyrotechnic device" used during a gender reveal party caused San Bernadino County's \#ElDoradoFire in Southern California"

On the other hand, neutral messages (NEU) have a Sentiment halfway between positive and negative and this can be due to two reasons: that the words used are really neutral (AGREEMENT) or that they contain both positive and negative words in the same message (DISAGREEMENT):

The messages from these three corpuses have been sorted by hand. Because they have a different format, a new global corpus will be created from the union of all of them, but with the strictly necessary information to train the supervised learning algorithms. The following table shows the number of tweets in each class and for each of

Rajoy: "We will try to share the costs of this economic crisis fairly. The first duty of a ruler is to be fair.

the collections to which they belong:

Table 1: Distribution of Number of Classes By Corpus

\begin{tabular}{|l|l|l|l|l|}
\hline & Positive (P) & $\begin{array}{l}\text { Negative } \\
(\mathbf{N})\end{array}$ & $\begin{array}{l}\text { Neutral } \\
(\text { NEU) }\end{array}$ & $\begin{array}{l}\text { No Sentiment } \\
(\text { NONE) }\end{array}$ \\
\hline General Corpus & 25237 & 18136 & 1965 & 22599 \\
\hline Politics Tweet & 623 & 621 & 943 & 231 \\
\hline $\begin{array}{l}\text { International } \\
\text { Tweet }\end{array}$ & 1236 & 1356 & 432 & 487 \\
\hline TOTAL (\%) & $23846(36 \%)$ & $\begin{array}{l}20121 \\
(27 \%)\end{array}$ & $3336(5 \%)$ & $23585(32 \%)$ \\
\hline
\end{tabular}

It is not difficult to see the great difference between the number of messages classified as neutral and the rest of the messages. Although the ideal in this type of test is that there is a balance between the number of samples of each class, sometimes this is not possible. This situation should be taken into account when measuring the effectiveness of classifiers.

\subsection{Metrics and Methods of Performance Evaluation}

In order to determine the performance of the algorithms and their configuration, a series of measures are needed to objectively evaluate their effectiveness in classifying the examples provided. In order to do so, it is important not only to take into account the correctly and incorrectly classified samples, but also those that, having been classified incorrectly, could have labeled well. To understand the four possible states of an example to be classified, let us think of a class A and an algorithm that determines whether or not the example belongs to that class:

a) True Positives (TP): these are the examples that have been correctly marked as belonging to class A. 
b) False Positives (FP): these will be the examples marked as class A, but they do not actually belong there, i.e. they have been incorrectly classified.

c) True Negatives (TN): in this case, the examples are not class A and have been correctly classified.

d) False Negatives (FN): this group will include examples marked as not belonging to class A, but in reality they are and therefore have not been correctly classified. Taking into account the above states, we can define the following measures that will be used to evaluate our models:

e) Accuracy: this is the simplest and most intuitive measure of performance and represents the ratio of correct predictions to total predictions made. In other words, it is the number of items correctly ranked among the total number of rankings performed.

Accuracy $=T P+T N / T P+F P+T N+F N$

It is common to think that the model that offers greater accuracy is the best model. In fact, this measure is appropriate in the case that the number of elements in each class is approximately the same and the corpus is balanced. Otherwise, it is necessary to make use of other types of measurements such as accuracy, completeness and F-value. Contrary to accuracy, these measures do not evaluate the performance of the model taking into account all the classes of the system, but they do it on individual classes. In other words, accuracy, completeness and $\mathrm{F}$-value will give different values for class $\mathrm{A}$ and $\mathrm{B}$.

a)Precision: is the ratio between the number of documents correctly classified as belonging to Class $\mathrm{A}$ and the total number of documents that have been classified by the model as Class A.

$$
\text { Precision }=T P / T P+F P
$$

Accuracy measures the proportion of positive identifications that are actually correct. Note that its value increases as the number of false positives decreases.

b)Completeness (from Recall): is the relationship between documents correctly classified as belonging to Class A and the sum of all Class A documents.

$$
\text { Recall }=T P / T P+F N
$$

Coverage is the proportion of actual positive elements correctly identified. It can also be seen as the model's ability to construct classes correctly. The closer to 1 , the better defined the different classes are, as their value increases as the number of false negatives decreases.

c) F-value (F-score): It is common for the coverage and completeness values to be used to measure the efficiency of a rating model. For this purpose, the F-value is presented as the harmonic mean between both measures and is usually used as a reference to compare the performance between several models. The F-value formula combines the two previous measures in a weighted way through a parameter $\beta$ which allows giving more importance to one than to the other.

d)Precision*RecalPrecision and completeness often have the same weight in the formula, i.e. with a value $\beta$ equal to 1 . This setting is known as F1-value or F1-score. In the case of a system with more than two classes, such as ours, each of the above metrics must be calculated for each class and combined between them to obtain an overall measurement.

e) Macro-averaging: in this case the measurements of each class are calculated and then the arithmetic mean is calculated:

\section{Experimental Result}

In this section we analysis the resultusing different algorithum to check the performance.

\subsection{Analysis of Tweet using Support Vector Machine}

Table 2 : Performance Analysis of SVM

\begin{tabular}{|r|l|l|l|l|l|l|l|}
\hline$\#$ & $\begin{array}{l}\text { PON } \\
\text { D. }\end{array}$ & $\begin{array}{l}\text { TWIT } \\
\text { TER }\end{array}$ & $\begin{array}{l}\text { STOPWO } \\
\text { RDS }\end{array}$ & $\begin{array}{l}\text { STEMM } \\
\text { ING }\end{array}$ & $\begin{array}{l}\text { PRECIS } \\
\text { ION }\end{array}$ & $\begin{array}{l}\text { REC } \\
\text { ALL }\end{array}$ & $\begin{array}{l}\text { F1- } \\
\text { SCO } \\
\text { RE }\end{array}$ \\
\hline 1 & BTO & $\begin{array}{l}\text { REMO } \\
\text { VE }\end{array}$ & FALSE & FALSE & $51,62 \%$ & $\begin{array}{l}51,62 \\
\%\end{array}$ & $\begin{array}{l}51,62 \\
\%\end{array}$ \\
\hline 2 & BTO & $\begin{array}{l}\text { REMO } \\
\text { VE }\end{array}$ & TRUE & FALSE & $54,87 \%$ & $\begin{array}{l}54,87 \\
\%\end{array}$ & $\begin{array}{l}54,87 \\
\%\end{array}$ \\
\hline
\end{tabular}




\begin{tabular}{|c|c|c|c|c|c|c|c|}
\hline 3 & ВТO & $\begin{array}{l}\text { REMO } \\
\text { VE }\end{array}$ & FALSE & TRUE & $50,38 \%$ & $\begin{array}{l}50,38 \\
\%\end{array}$ & $\begin{array}{l}50,38 \\
\%\end{array}$ \\
\hline 4 & ВTO & $\begin{array}{l}\text { REMO } \\
\text { VE }\end{array}$ & TRUE & TRUE & $52,51 \%$ & $\begin{array}{l}52,51 \\
\%\end{array}$ & $\begin{array}{l}52,51 \\
\%\end{array}$ \\
\hline 5 & ВТO & $\begin{array}{l}\text { NORM } \\
\text { AL. }\end{array}$ & FALSE & FALSE & $52,34 \%$ & $\begin{array}{l}52,34 \\
\%\end{array}$ & $\begin{array}{l}52,34 \\
\%\end{array}$ \\
\hline 6 & ВТO & $\begin{array}{l}\text { NORM } \\
\text { AL. }\end{array}$ & TRUE & FALSE & $54,34 \%$ & $\begin{array}{l}54,34 \\
\% \\
\end{array}$ & $\begin{array}{l}54,34 \\
\% \\
\end{array}$ \\
\hline 7 & BTO & $\begin{array}{l}\text { NORM } \\
\text { AL. }\end{array}$ & FALSE & TRUE & $49,67 \%$ & $\begin{array}{l}49,67 \\
\%\end{array}$ & $\begin{array}{l}49,67 \\
\%\end{array}$ \\
\hline 8 & ВTO & $\begin{array}{l}\text { NORM } \\
\text { AL. }\end{array}$ & TRUE & TRUE & $53,51 \%$ & $\begin{array}{l}53,51 \\
\%\end{array}$ & $\begin{array}{l}53,51 \\
\%\end{array}$ \\
\hline 9 & TO & $\begin{array}{l}\text { REMO } \\
\text { VE }\end{array}$ & FALSE & FALSE & $51,53 \%$ & $\begin{array}{l}51,53 \\
\%\end{array}$ & $\begin{array}{l}51,53 \\
\%\end{array}$ \\
\hline $\begin{array}{l}1 \\
0\end{array}$ & TO & $\begin{array}{l}\text { REMO } \\
\text { VE }\end{array}$ & TRUE & FALSE & $54,60 \%$ & $\begin{array}{l}54,60 \\
\%\end{array}$ & $\begin{array}{l}54,60 \\
\%\end{array}$ \\
\hline $\begin{array}{l}1 \\
1\end{array}$ & TO & $\begin{array}{l}\text { REMO } \\
\text { VE }\end{array}$ & FALSE & TRUE & $49,79 \%$ & $\begin{array}{l}49,79 \\
\%\end{array}$ & $\begin{array}{l}49,79 \\
\%\end{array}$ \\
\hline $\begin{array}{l}1 \\
2\end{array}$ & TO & $\begin{array}{l}\text { REMO } \\
\text { VE }\end{array}$ & TRUE & TRUE & $51,62 \%$ & $\begin{array}{l}51,62 \\
\%\end{array}$ & $\begin{array}{l}51,62 \\
\%\end{array}$ \\
\hline $\begin{array}{l}1 \\
3 \\
\end{array}$ & TO & $\begin{array}{l}\text { NORM } \\
\text { AL. }\end{array}$ & FALSE & FALSE & $54,87 \%$ & $\begin{array}{l}54,87 \\
\% \\
\end{array}$ & $\begin{array}{l}54,87 \\
\% \\
\end{array}$ \\
\hline $\begin{array}{l}1 \\
4 \\
\end{array}$ & TO & $\begin{array}{l}\text { NORM } \\
\text { AL. }\end{array}$ & TRUE & FALSE & $50,38 \%$ & $\begin{array}{l}50,38 \\
\% \\
\end{array}$ & $\begin{array}{l}50,38 \\
\% \\
\end{array}$ \\
\hline $\begin{array}{l}1 \\
5 \\
\end{array}$ & TO & $\begin{array}{l}\text { NORM } \\
\text { AL. }\end{array}$ & FALSE & TRUE & $52,51 \%$ & $\begin{array}{l}52,51 \\
\%\end{array}$ & $\begin{array}{l}52,51 \\
\%\end{array}$ \\
\hline $\begin{array}{l}1 \\
6 \\
\end{array}$ & TO & $\begin{array}{l}\text { NORM } \\
\text { AL. }\end{array}$ & TRUE & TRUE & $52,34 \%$ & $\begin{array}{l}52,34 \\
\% \\
\end{array}$ & $\begin{array}{l}52,34 \\
\% \\
\end{array}$ \\
\hline $\begin{array}{l}1 \\
7\end{array}$ & BTO & $\begin{array}{l}\text { REMO } \\
\text { VE }\end{array}$ & TRUE & TRUE & $52,51 \%$ & $\begin{array}{l}52,51 \\
\%\end{array}$ & $\begin{array}{l}52,51 \\
\%\end{array}$ \\
\hline $\begin{array}{l}1 \\
8\end{array}$ & BTO & $\begin{array}{l}\text { NORM } \\
\text { AL. }\end{array}$ & FALSE & FALSE & $52,34 \%$ & $\begin{array}{l}52,34 \\
\%\end{array}$ & $\begin{array}{l}52,34 \\
\%\end{array}$ \\
\hline $\begin{array}{l}1 \\
9\end{array}$ & ВTO & $\begin{array}{l}\text { NORM } \\
\text { AL. }\end{array}$ & TRUE & FALSE & $54,34 \%$ & $\begin{array}{l}54,34 \\
\%\end{array}$ & $\begin{array}{l}54,34 \\
\%\end{array}$ \\
\hline $\begin{array}{l}2 \\
0\end{array}$ & BTO & $\begin{array}{l}\text { NORM } \\
\text { AL. }\end{array}$ & FALSE & TRUE & $49,67 \%$ & $\begin{array}{l}49,67 \\
\%\end{array}$ & $\begin{array}{l}49,67 \\
\%\end{array}$ \\
\hline $\begin{array}{l}2 \\
1\end{array}$ & $\mathrm{TF}$ & $\begin{array}{l}\text { NORM } \\
\text { AL. }\end{array}$ & FALSE & FALSE & $51,62 \%$ & $\begin{array}{l}51,62 \\
\%\end{array}$ & $\begin{array}{l}51,62 \\
\%\end{array}$ \\
\hline $\begin{array}{l}2 \\
2 \\
\end{array}$ & $\mathrm{TF}$ & $\begin{array}{l}\text { NORM } \\
\text { AL. }\end{array}$ & TRUE & FALSE & $54,87 \%$ & $\begin{array}{l}54,87 \\
\% \\
\end{array}$ & $\begin{array}{l}54,87 \\
\% \\
\end{array}$ \\
\hline $\begin{array}{l}2 \\
3 \\
\end{array}$ & $\mathrm{TF}$ & $\begin{array}{l}\text { NORM } \\
\text { AL. }\end{array}$ & FALSE & TRUE & $50,38 \%$ & $\begin{array}{l}50,38 \\
\%\end{array}$ & $\begin{array}{l}50,38 \\
\%\end{array}$ \\
\hline $\begin{array}{l}2 \\
4 \\
\end{array}$ & $\mathrm{TF}$ & $\begin{array}{l}\text { NORM } \\
\text { AL. }\end{array}$ & TRUE & TRUE & $51,62 \%$ & $\begin{array}{l}51,62 \\
\% \\
\end{array}$ & $\begin{array}{l}51,62 \\
\% \\
\end{array}$ \\
\hline $\begin{array}{l}2 \\
5 \\
\end{array}$ & $\begin{array}{l}\text { TF- } \\
\text { IDF }\end{array}$ & $\begin{array}{l}\text { REMO } \\
\text { VE }\end{array}$ & FALSE & FALSE & $54,87 \%$ & $\begin{array}{l}54,87 \\
\% \\
\end{array}$ & $\begin{array}{l}54,87 \\
\%\end{array}$ \\
\hline $\begin{array}{l}2 \\
6 \\
\end{array}$ & $\begin{array}{l}\text { TF- } \\
\text { IDF }\end{array}$ & $\begin{array}{l}\text { REMO } \\
\text { VE }\end{array}$ & TRUE & FALSE & $50,38 \%$ & $\begin{array}{l}50,38 \\
\% \\
\end{array}$ & $\begin{array}{l}50,38 \\
\%\end{array}$ \\
\hline $\begin{array}{l}2 \\
7 \\
\end{array}$ & $\begin{array}{l}\text { TF- } \\
\text { IDF }\end{array}$ & $\begin{array}{l}\text { REMO } \\
\text { VE }\end{array}$ & FALSE & TRUE & $52,51 \%$ & $\begin{array}{l}52,51 \\
\% \\
\end{array}$ & $\begin{array}{l}52,51 \\
\%\end{array}$ \\
\hline $\begin{array}{l}2 \\
8 \\
\end{array}$ & $\begin{array}{l}\text { TF- } \\
\text { IDF }\end{array}$ & $\begin{array}{l}\text { REMO } \\
\text { VE }\end{array}$ & TRUE & TRUE & $52,34 \%$ & $\begin{array}{l}52,34 \\
\% \\
\end{array}$ & $\begin{array}{l}52,34 \\
\% \\
\end{array}$ \\
\hline $\begin{array}{l}2 \\
9 \\
\end{array}$ & $\begin{array}{l}\text { TF- } \\
\text { IDF }\end{array}$ & $\begin{array}{l}\text { NORM } \\
\text { AL }\end{array}$ & FALSE & FALSE & $54,34 \%$ & $\begin{array}{l}54,34 \\
\% \\
\end{array}$ & $\begin{array}{l}54,34 \\
\% \\
\end{array}$ \\
\hline $\begin{array}{l}3 \\
0 \\
\end{array}$ & $\begin{array}{l}\text { TF- } \\
\text { IDF }\end{array}$ & $\begin{array}{l}\text { NORM } \\
\text { AL }\end{array}$ & TRUE & FALSE & $49,67 \%$ & $\begin{array}{l}49,67 \\
\% \\
\end{array}$ & $\begin{array}{l}49,67 \\
\% \\
\end{array}$ \\
\hline $\begin{array}{l}3 \\
1 \\
\end{array}$ & $\begin{array}{l}\text { TF- } \\
\text { IDF }\end{array}$ & $\begin{array}{l}\text { NORM } \\
\mathrm{AL} \\
\end{array}$ & FALSE & TRUE & $53,51 \%$ & $\begin{array}{l}53,51 \\
\% \\
\end{array}$ & $\begin{array}{l}53,51 \\
\% \\
\end{array}$ \\
\hline
\end{tabular}




\begin{tabular}{|l|l|l|l|l|l|l|l|}
3 & TF- & NORM & TRUE & TRUE & $51,53 \%$ & $\begin{array}{l}51,53 \\
\%\end{array}$ & $\begin{array}{l}51,53 \\
\%\end{array}$ \\
\hline
\end{tabular}

4.3 Analysis using Naive Bayes

Table 3: Performance Analysis of Naive Bayes

\begin{tabular}{|c|c|c|c|c|c|c|c|}
\hline$\#$ & $\begin{array}{l}\text { PON } \\
\text { D. }\end{array}$ & $\begin{array}{l}\text { TWITT } \\
\text { ER }\end{array}$ & $\begin{array}{l}\text { STOPW } \\
\text { ORDS }\end{array}$ & $\begin{array}{l}\text { STEM } \\
\text { MING }\end{array}$ & $\begin{array}{l}\text { PRECI } \\
\text { SION }\end{array}$ & $\begin{array}{l}\text { RECA } \\
\text { LL }\end{array}$ & $\begin{array}{l}\text { F1- } \\
\text { SCOR } \\
\text { E }\end{array}$ \\
\hline 1 & ВТO & $\begin{array}{l}\text { REMO } \\
\text { VE }\end{array}$ & FALSE & FALSE & $\begin{array}{l}\text { PRECIS } \\
\text { ION }\end{array}$ & $\begin{array}{l}\text { RECA } \\
\text { LL }\end{array}$ & $\begin{array}{l}\text { F1- } \\
\text { SCOR } \\
\text { E }\end{array}$ \\
\hline 2 & BTO & $\begin{array}{l}\text { REMO } \\
\text { VE }\end{array}$ & TRUE & FALSE & $61,54 \%$ & $63,20 \%$ & $\begin{array}{l}60,82 \\
\%\end{array}$ \\
\hline 3 & BTO & $\begin{array}{l}\text { REMO } \\
\text { VE }\end{array}$ & FALSE & TRUE & $60,69 \%$ & $62,74 \%$ & $\begin{array}{l}60,47 \\
\%\end{array}$ \\
\hline 4 & BTO & $\begin{array}{l}\text { REMO } \\
\text { VE }\end{array}$ & TRUE & TRUE & $61,04 \%$ & $63,25 \%$ & $\begin{array}{l}61,04 \\
\%\end{array}$ \\
\hline 5 & ВТO & $\begin{array}{l}\text { NORM } \\
\text { AL }\end{array}$ & FALSE & FALSE & $60,50 \%$ & $62,89 \%$ & $\begin{array}{l}60,69 \\
\%\end{array}$ \\
\hline 6 & ВTO & $\begin{array}{l}\text { NORM } \\
\text { AL }\end{array}$ & TRUE & FALSE & $62,67 \%$ & $\begin{array}{l}64,52 \\
\%\end{array}$ & $\begin{array}{l}62,39 \\
\% \\
\end{array}$ \\
\hline 7 & BTO & $\begin{array}{l}\text { NORM } \\
\text { AL }\end{array}$ & FALSE & TRUE & $62,31 \%$ & $63,94 \%$ & $\begin{array}{l}61,90 \\
\%\end{array}$ \\
\hline 8 & ВTO & $\begin{array}{l}\text { NORM } \\
\text { AL }\end{array}$ & TRUE & TRUE & $62,13 \%$ & $\begin{array}{l}64,37 \\
\%\end{array}$ & $\begin{array}{l}62,39 \\
\% \\
\end{array}$ \\
\hline 9 & TO & $\begin{array}{l}\text { REMO } \\
\text { VE }\end{array}$ & $\overline{\text { FALSE }}$ & FALSE & $61,63 \%$ & $64,09 \%$ & $\begin{array}{l}62,10 \\
\%\end{array}$ \\
\hline $\begin{array}{l}1 \\
0\end{array}$ & $\mathrm{TO}$ & $\begin{array}{l}\text { REMO } \\
\text { VE }\end{array}$ & TRUE & FALSE & $61,58 \%$ & $63,06 \%$ & $\begin{array}{l}60,73 \\
\%\end{array}$ \\
\hline $\begin{array}{l}1 \\
1\end{array}$ & TO & $\begin{array}{l}\text { REMO } \\
\text { VE }\end{array}$ & FALSE & TRUE & $60,26 \%$ & $62,29 \%$ & $\begin{array}{l}60,08 \\
\%\end{array}$ \\
\hline $\begin{array}{l}1 \\
2\end{array}$ & TO & $\begin{array}{l}\text { REMO } \\
\text { VE }\end{array}$ & TRUE & TRUE & $60,78 \%$ & $62,77 \%$ & $\begin{array}{l}60,63 \\
\%\end{array}$ \\
\hline $\begin{array}{l}1 \\
3 \\
\end{array}$ & TO & $\begin{array}{l}\text { NORM } \\
\text { AL }\end{array}$ & FALSE & $\overline{\text { FALSE }}$ & $60,15 \%$ & $62,42 \%$ & $\begin{array}{l}60,29 \\
\% \\
\end{array}$ \\
\hline $\begin{array}{l}1 \\
4 \\
\end{array}$ & TO & $\begin{array}{l}\text { NORM } \\
\text { AL }\end{array}$ & TRUE & FALSE & $62,19 \%$ & $63,88 \%$ & $\begin{array}{l}61,79 \\
\% \\
\end{array}$ \\
\hline $\begin{array}{l}1 \\
5\end{array}$ & TO & $\begin{array}{l}\text { NORM } \\
\text { AL }\end{array}$ & FALSE & TRUE & $61,18 \%$ & $63,28 \%$ & $\begin{array}{l}61,25 \\
\% \\
\end{array}$ \\
\hline $\begin{array}{l}1 \\
6 \\
\end{array}$ & TO & $\begin{array}{l}\text { NORM } \\
\text { AL }\end{array}$ & TRUE & TRUE & $61,88 \%$ & $63,77 \%$ & $\begin{array}{l}61,84 \\
\%\end{array}$ \\
\hline $\begin{array}{l}1 \\
7 \\
\end{array}$ & TF & $\begin{array}{l}\text { REMO } \\
\text { VE }\end{array}$ & $\overline{\text { FALSE }}$ & $\overline{\text { FALSE }}$ & $60,86 \%$ & $63,25 \%$ & $\begin{array}{l}61,33 \\
\%\end{array}$ \\
\hline $\begin{array}{l}1 \\
8\end{array}$ & TF & $\begin{array}{l}\text { REMO } \\
\text { VE }\end{array}$ & TRUE & $\overline{\text { FALSE }}$ & $59,10 \%$ & $59,07 \%$ & $\begin{array}{l}55,48 \\
\%\end{array}$ \\
\hline $\begin{array}{l}1 \\
9\end{array}$ & $\mathrm{TF}$ & $\begin{array}{l}\text { REMO } \\
\text { VE }\end{array}$ & FALSE & TRUE & $59,24 \%$ & $60,82 \%$ & $\begin{array}{l}57,91 \\
\%\end{array}$ \\
\hline $\begin{array}{l}2 \\
0\end{array}$ & $\mathrm{TF}$ & $\begin{array}{l}\text { REMO } \\
\text { VE }\end{array}$ & TRUE & TRUE & $59,66 \%$ & $60,79 \%$ & $\begin{array}{l}57,58 \\
\%\end{array}$ \\
\hline $\begin{array}{l}2 \\
1\end{array}$ & $\mathrm{TF}$ & $\begin{array}{l}\text { NORM } \\
\text { AL }\end{array}$ & FALSE & FALSE & $59,64 \%$ & $61,45 \%$ & $\begin{array}{l}58,56 \\
\%\end{array}$ \\
\hline $\begin{array}{l}2 \\
2\end{array}$ & $\mathrm{TF}$ & $\begin{array}{l}\text { NORM } \\
\text { AL }\end{array}$ & TRUE & FALSE & $59,53 \%$ & $59,23 \%$ & $\begin{array}{l}55,99 \\
\%\end{array}$ \\
\hline \begin{tabular}{l|}
2 \\
3
\end{tabular} & $\mathrm{TF}$ & $\begin{array}{l}\text { NORM } \\
\text { AL }\end{array}$ & $\overline{\text { FALSE }}$ & TRUE & $59,16 \%$ & $60,29 \%$ & $\begin{array}{l}57,52 \\
\%\end{array}$ \\
\hline $\begin{array}{l}2 \\
4 \\
\end{array}$ & $\mathrm{TF}$ & $\begin{array}{l}\text { NORM } \\
\text { AL }\end{array}$ & TRUE & TRUE & $59,94 \%$ & $60,94 \%$ & $\begin{array}{l}57,99 \\
\%\end{array}$ \\
\hline
\end{tabular}




\begin{tabular}{|c|c|c|c|c|c|c|c|}
\hline $\begin{array}{l}2 \\
5\end{array}$ & $\begin{array}{l}\text { TF- } \\
\text { IDF }\end{array}$ & $\begin{array}{l}\text { REMO } \\
\text { VE }\end{array}$ & FALSE & FALSE & $59,89 \%$ & $61,45 \%$ & $\begin{array}{l}58,78 \\
\%\end{array}$ \\
\hline $\begin{array}{l}2 \\
6\end{array}$ & $\begin{array}{l}\text { TF- } \\
\text { IDF }\end{array}$ & $\begin{array}{l}\text { REMO } \\
\text { VE }\end{array}$ & TRUE & FALSE & $60,03 \%$ & $61,68 \%$ & $\begin{array}{l}58,71 \\
\%\end{array}$ \\
\hline $\begin{array}{l}2 \\
7\end{array}$ & $\begin{array}{l}\text { TF- } \\
\text { IDF }\end{array}$ & $\begin{array}{l}\text { REMO } \\
\text { VE }\end{array}$ & FALSE & TRUE & $59,67 \%$ & $61,92 \%$ & $\begin{array}{l}59,28 \\
\%\end{array}$ \\
\hline $\begin{array}{l}2 \\
8 \\
\end{array}$ & $\begin{array}{l}\text { TF- } \\
\text { IDF } \\
\end{array}$ & $\begin{array}{l}\text { REMO } \\
\text { VE }\end{array}$ & TRUE & TRUE & $59,73 \%$ & $61,94 \%$ & $\begin{array}{l}59,07 \\
\%\end{array}$ \\
\hline $\begin{array}{l}2 \\
9\end{array}$ & $\begin{array}{l}\text { TF- } \\
\text { IDF }\end{array}$ & $\begin{array}{l}\text { NORM } \\
\text { AL }\end{array}$ & $\overline{\text { FALSE }}$ & FALSE & $59,45 \%$ & $61,91 \%$ & $\begin{array}{l}59,26 \\
\%\end{array}$ \\
\hline $\begin{array}{l}3 \\
0\end{array}$ & $\begin{array}{l}\text { TF- } \\
\text { IDF }\end{array}$ & $\begin{array}{l}\text { NORM } \\
\text { AL }\end{array}$ & TRUE & $\overline{\text { FALSE }}$ & $60,57 \%$ & $62,12 \%$ & $\begin{array}{l}59,33 \\
\%\end{array}$ \\
\hline $\begin{array}{l}3 \\
1\end{array}$ & $\begin{array}{l}\text { TF- } \\
\text { IDF }\end{array}$ & $\begin{array}{l}\text { NORM } \\
\text { AL }\end{array}$ & FALSE & TRUE & $60,13 \%$ & $62,26 \%$ & $\begin{array}{l}59,75 \\
\%\end{array}$ \\
\hline $\begin{array}{l}3 \\
2\end{array}$ & $\begin{array}{l}\text { TF- } \\
\text { IDF }\end{array}$ & $\begin{array}{l}\text { NORM } \\
\text { AL }\end{array}$ & TRUE & TRUE & $60,69 \%$ & $62,74 \%$ & $\begin{array}{l}60,09 \\
\%\end{array}$ \\
\hline
\end{tabular}

\subsection{Analysis using Random Forest Tree}

Table 4: Performance Analysis of Random Forest Tree

\begin{tabular}{|c|c|c|c|c|c|c|c|}
\hline \# & $\begin{array}{l}\text { PO } \\
\text { ND } \\
.\end{array}$ & $\begin{array}{l}\text { TWITTE } \\
\mathbf{R}\end{array}$ & $\begin{array}{l}\text { STOPW } \\
\text { ORDS }\end{array}$ & $\begin{array}{l}\text { STEM } \\
\text { MING }\end{array}$ & $\begin{array}{l}\text { PRECISI } \\
\text { ON }\end{array}$ & $\begin{array}{l}\text { REC } \\
\text { ALL }\end{array}$ & $\begin{array}{l}\text { F1- } \\
\text { SCOR } \\
\text { E }\end{array}$ \\
\hline 1 & $\begin{array}{l}\text { BT } \\
\text { O }\end{array}$ & REMOVE & FALSE & FALSE & $51,92 \%$ & $\begin{array}{l}51,92 \\
\%\end{array}$ & $51,92 \%$ \\
\hline 2 & $\begin{array}{l}\text { BT } \\
\text { O }\end{array}$ & REMOVE & TRUE & FALSE & $56,18 \%$ & $\begin{array}{l}56,18 \\
\%\end{array}$ & $56,18 \%$ \\
\hline 3 & $\begin{array}{l}\text { BT } \\
\text { O }\end{array}$ & REMOVE & FALSE & TRUE & $51,92 \%$ & $\begin{array}{l}51,92 \\
\%\end{array}$ & $51,92 \%$ \\
\hline 4 & $\begin{array}{l}\text { BT } \\
\mathrm{O}\end{array}$ & REMOVE & TRUE & TRUE & $56,18 \%$ & $\begin{array}{l}56,18 \\
\%\end{array}$ & $56,18 \%$ \\
\hline 5 & $\begin{array}{l}\text { BT } \\
\mathrm{O} \\
\end{array}$ & NORMAL & FALSE & FALSE & $53,53 \%$ & $\begin{array}{l}53,53 \\
\% \\
\end{array}$ & $53,53 \%$ \\
\hline 6 & $\begin{array}{l}\text { BT } \\
\mathrm{O} \\
\end{array}$ & NORMAL & TRUE & FALSE & $56,61 \%$ & $\begin{array}{l}56,61 \\
\%\end{array}$ & $56,61 \%$ \\
\hline 7 & $\begin{array}{l}\text { BT } \\
\text { O }\end{array}$ & NORMAL & FALSE & TRUE & $52,03 \%$ & $\begin{array}{l}52,03 \\
\%\end{array}$ & $52,03 \%$ \\
\hline 8 & $\begin{array}{l}\text { BT } \\
\text { O }\end{array}$ & NORMAL & TRUE & TRUE & $55,36 \%$ & $\begin{array}{l}55,36 \\
\%\end{array}$ & $55,36 \%$ \\
\hline 9 & $\mathrm{TO}$ & REMOVE & FALSE & FALSE & $53,43 \%$ & $\begin{array}{l}53,43 \\
\%\end{array}$ & $53,43 \%$ \\
\hline $\begin{array}{l}1 \\
0\end{array}$ & TO & REMOVE & TRUE & FALSE & $56,23 \%$ & $\begin{array}{l}56,23 \\
\%\end{array}$ & $56,23 \%$ \\
\hline $\begin{array}{l}1 \\
1\end{array}$ & TO & REMOVE & FALSE & TRUE & $51,88 \%$ & $\begin{array}{l}51,88 \\
\%\end{array}$ & $51,88 \%$ \\
\hline $\begin{array}{l}1 \\
2\end{array}$ & TO & REMOVE & TRUE & TRUE & $55,32 \%$ & $\begin{array}{l}55,32 \\
\%\end{array}$ & $55,32 \%$ \\
\hline $\begin{array}{l}1 \\
3\end{array}$ & TO & NORMAL & FALSE & FALSE & $53,04 \%$ & $\begin{array}{l}53,04 \\
\%\end{array}$ & $53,04 \%$ \\
\hline $\begin{array}{l}1 \\
4 \\
\end{array}$ & TO & NORMAL & TRUE & FALSE & $56,09 \%$ & $\begin{array}{l}56,09 \\
\% \\
\end{array}$ & $56,09 \%$ \\
\hline $\begin{array}{l}1 \\
5\end{array}$ & TO & NORMAL & FALSE & TRUE & $52,34 \%$ & $\begin{array}{l}52,34 \\
\% \\
\end{array}$ & $52,34 \%$ \\
\hline $\begin{array}{l}1 \\
6\end{array}$ & TO & NORMAL & TRUE & TRUE & $54,67 \%$ & $\begin{array}{l}54,67 \\
\%\end{array}$ & $54,67 \%$ \\
\hline $\begin{array}{l}1 \\
7\end{array}$ & $\mathrm{TF}$ & REMOVE & FALSE & FALSE & $53,12 \%$ & $\begin{array}{l}53,12 \\
\%\end{array}$ & $53,12 \%$ \\
\hline $\begin{array}{l}1 \\
8 \\
\end{array}$ & $\mathrm{TF}$ & REMOVE & TRUE & FALSE & $55,71 \%$ & $\begin{array}{l}55,71 \\
\%\end{array}$ & $55,71 \%$ \\
\hline
\end{tabular}




\begin{tabular}{|c|c|c|c|c|c|c|c|}
\hline $\begin{array}{l}1 \\
9\end{array}$ & TF & REMOVE & FALSE & TRUE & $50,50 \%$ & $\begin{array}{l}50,50 \\
\%\end{array}$ & $50,50 \%$ \\
\hline $\begin{array}{l}2 \\
0\end{array}$ & $\mathrm{TF}$ & REMOVE & TRUE & TRUE & $54,06 \%$ & $\begin{array}{l}54,06 \\
\%\end{array}$ & $54,06 \%$ \\
\hline $\begin{array}{l}2 \\
1\end{array}$ & $\mathrm{TF}$ & NORMAL & FALSE & FALSE & $51,62 \%$ & $\begin{array}{l}51,62 \\
\%\end{array}$ & $51,62 \%$ \\
\hline $\begin{array}{l}2 \\
2\end{array}$ & $\mathrm{TF}$ & NORMAL & TRUE & FALSE & $54,87 \%$ & $\begin{array}{l}54,87 \\
\%\end{array}$ & $54,87 \%$ \\
\hline $\begin{array}{l}2 \\
3\end{array}$ & $\mathrm{TF}$ & NORMAL & FALSE & TRUE & $50,38 \%$ & $\begin{array}{l}50,38 \\
\%\end{array}$ & $50,38 \%$ \\
\hline $\begin{array}{l}2 \\
4 \\
\end{array}$ & $\mathrm{TF}$ & NORMAL & TRUE & TRUE & $52,51 \%$ & $\begin{array}{l}52,51 \\
\%\end{array}$ & $52,51 \%$ \\
\hline $\begin{array}{l}2 \\
5\end{array}$ & $\begin{array}{l}\text { TF- } \\
\text { ID } \\
\text { F }\end{array}$ & REMOVE & FALSE & FALSE & $52,34 \%$ & $\begin{array}{l}52,34 \\
\%\end{array}$ & $52,34 \%$ \\
\hline $\begin{array}{l}2 \\
6\end{array}$ & $\begin{array}{l}\text { TF- } \\
\text { ID } \\
\text { F } \\
\end{array}$ & REMOVE & TRUE & FALSE & $54,34 \%$ & $\begin{array}{l}54,34 \\
\%\end{array}$ & $54,34 \%$ \\
\hline $\begin{array}{l}2 \\
7\end{array}$ & $\begin{array}{l}\text { TF- } \\
\text { ID } \\
\text { F } \\
\end{array}$ & REMOVE & FALSE & TRUE & $49,67 \%$ & $\begin{array}{l}49,67 \\
\%\end{array}$ & $49,67 \%$ \\
\hline $\begin{array}{l}2 \\
8\end{array}$ & $\begin{array}{l}\text { TF- } \\
\text { ID } \\
\text { F }\end{array}$ & REMOVE & TRUE & TRUE & $53,51 \%$ & $\begin{array}{l}53,51 \\
\%\end{array}$ & $53,51 \%$ \\
\hline $\begin{array}{l}2 \\
9\end{array}$ & $\begin{array}{l}\text { TF- } \\
\text { ID } \\
\text { F }\end{array}$ & NORMAL & FALSE & FALSE & $51,53 \%$ & $\begin{array}{l}51,53 \\
\%\end{array}$ & $51,53 \%$ \\
\hline $\begin{array}{l}3 \\
0\end{array}$ & $\begin{array}{l}\text { TF- } \\
\text { ID } \\
\text { F } \\
\end{array}$ & NORMAL & TRUE & FALSE & $54,60 \%$ & $\begin{array}{l}54,60 \\
\%\end{array}$ & $54,60 \%$ \\
\hline $\begin{array}{l}3 \\
1\end{array}$ & $\begin{array}{l}\text { TF- } \\
\text { ID } \\
\text { F } \\
\end{array}$ & NORMAL & FALSE & TRUE & $49,79 \%$ & $\begin{array}{l}49,79 \\
\%\end{array}$ & $49,79 \%$ \\
\hline $\begin{array}{l}3 \\
2\end{array}$ & $\begin{array}{l}\text { TF- } \\
\text { ID } \\
\text { F } \\
\end{array}$ & $\begin{array}{l}\text { NORMAL } \\
\text {. }\end{array}$ & TRUE & TRUE & $51,31 \%$ & $\begin{array}{l}51,31 \\
\%\end{array}$ & $51,31 \%$ \\
\hline
\end{tabular}

There is no doubt that the winning algorithm is the support vector machine and, the one with the worst results in general terms, random Forest. However, in one of the experiments it manages to obtain a higher yield than the decision trees, thus coming in third position. This bar chart shows the best values for the four tested algorithms:

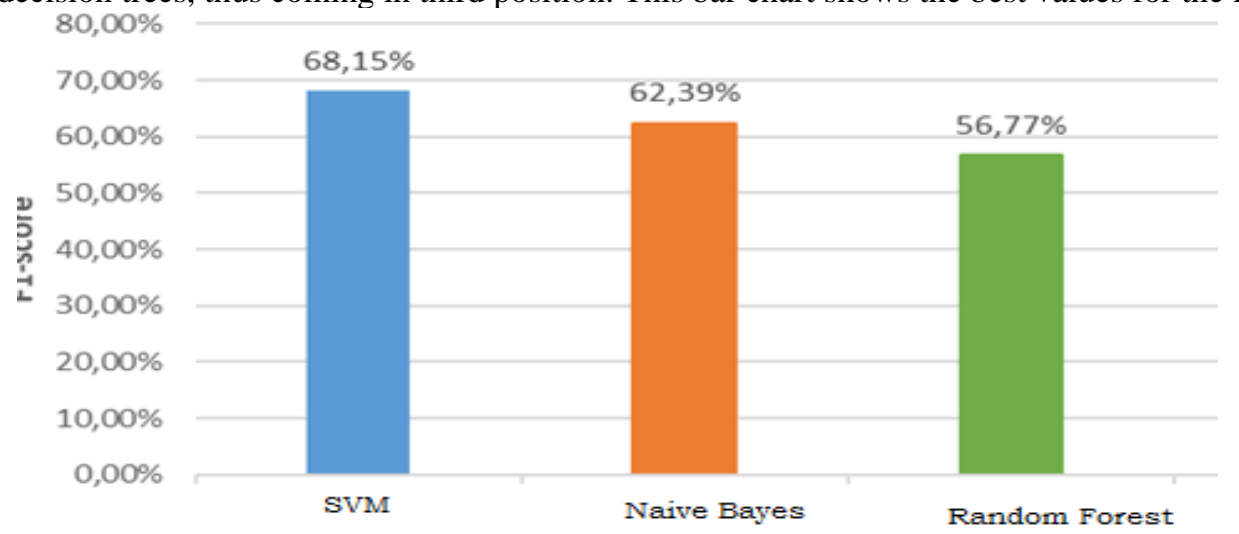

Score Comparison

Figure 2: Maximum F1

\section{Conclusion}

This work provides valuable knowledge of the roots of sentiment analysis and how sentiment evaluators can be configured. We demonstrated how to construct a basic classifier and use it as an example. These approaches will 
eventually change and there will still be the need for a more extensive assessment of emotions. Non-textual material has an important significance in analyses. Photos, photographs, animations and other visual material are also useful in performing social research. Of course I can see that all these hyperlinks provide essential material. Some other ways of using social media are likes, retweets, reviews on posts and much more! It is hoped that common issues such as avoiding irony and sarcasm would be made less ambiguous. However, there will emerge other issues that will have to be tackled.

\section{REFERENCES}

1. G. Xu, Z. Yu, H. Yao, F. Li, Y. Meng and X. Wu, "Chinese Text Sentiment Analysis Based on Extended Sentiment Dictionary," in IEEE Access, vol. 7, pp. 43749-43762, 2019. doi: 10.1109/ACCESS.2019.2907772.

2. L. Yang, Y. Li, J. Wang and R. S. Sherratt, "Sentiment Analysis for E-Commerce Product Reviews in Chinese Based on Sentiment Lexicon and Deep Learning," in IEEE Access, vol. 8, pp. 2352223530, 2020.doi: 10.1109/ACCESS.2020.2969854.

3. Z. Li, R. Li and G. Jin, "Sentiment Analysis of Danmaku Videos Based on Naïve Bayes and Sentiment Dictionary," in IEEE Access, vol. 8, pp. 75073-75084, 2020.doi: 10.1109/ACCESS.2020.2986582.

4. J. Wu, K. Lu, S. Su and S. Wang, "Chinese Micro-Blog Sentiment Analysis Based on Multiple Sentiment Dictionaries and Semantic Rule Sets," in IEEE Access, vol. 7, pp. 183924-183939, 2019.doi: 10.1109/ACCESS.2019.2960655.

5. L. Wang, J. Niu and S. Yu, "SentiDiff: Combining Textual Information and Sentiment Diffusion Patterns for Twitter Sentiment Analysis," in IEEE Transactions on Knowledge and Data Engineering, vol. 32, no. 10, pp. 2026-2039, 1 Oct. 2020.doi: 10.1109/TKDE.2019.2913641.

6. B. Zhang, D. Xu, H. Zhang and M. Li, "STCS Lexicon: Spectral-Clustering-Based Topic-Specific Chinese Sentiment Lexicon Construction for Social Networks," in IEEE Transactions on Computational Social Systems, vol. 6, no. 6, pp. 1180-1189, Dec. 2019.doi: 10.1109/TCSS.2019.2941344.

7. Dr.J. Preetha and Dr.S.Lavanya" Security Based Service Infrastructure for Wireless Adhoc Networks using Fuzzy Logic" PAIDEUMA JOURNAL OF RESEARCH, ISSN No: 00905674 at Volume-XIII Issue-II, FEBRUARY 2020Pg:103-108

8. L. Kaushik, A. Sangwan and J. H. L. Hansen, "Automatic Sentiment Detection in Naturalistic Audio," in IEEE/ACM Transactions on Audio, Speech, and Language Processing, vol. 25, no. 8, pp. 1668-1679, Aug. 2017.doi: 10.1109/TASLP.2017.2678164.

9. V.D. Ambeth Kumar,*, S. Malathia, R. Venkatesan, K. Ramalakshmi, K. Vengatesan,Weiping Ding and Abhishek Kumar,"Exploration of an innovative geometric parameter based on performance enhancement for foot print recognition",Journal of Intelligent \& Fuzzy Systems.

10. H. T. Phan, V. C. Tran, N. T. Nguyen and D. Hwang, "Improving the Performance of Sentiment Analysis of Tweets Containing Fuzzy Sentiment Using the Feature Ensemble Model," in IEEE Access, vol. 8, pp. 14630-14641, 2020. doi: 10.1109/ACCESS.2019.2963702.

11. Y. Gao, J. Liu, P. Li and D. Zhou, "CE-HEAT: An Aspect-Level Sentiment Classification Approach With Collaborative Extraction Hierarchical Attention Network," in IEEE Access, vol. 7, pp. 168548168556, 2019.doi: 10.1109/ACCESS.2019.2954590.

12. F. Yin, Y. Wang, J. Liu and L. Lin, "The Construction of Sentiment Lexicon Based on ContextDependent Part-of-Speech Chunks for Semantic Disambiguation," in IEEE Access, vol. 8, pp. 63359-63367, 2020.doi: 10.1109/ACCESS.2020.2984284.

13. L. Yu, J. Wang, K. R. Lai and X. Zhang, "Refining Word Embeddings Using Intensity Scores for Sentiment Analysis," in IEEE/ACM Transactions on Audio, Speech, and Language Processing, vol. 26, no. 3, pp. 671-681, March 2018. doi: 10.1109/TASLP.2017.2788182.

14. H. Liang, U. Ganeshbabu and T. Thorne, "A Dynamic Bayesian Network Approach for Analysing Topic-Sentiment Evolution," in IEEE Access, vol. 8, pp. 54164-54174, 2020. doi: 10.1109/ACCESS.2020.2979012.

15. Saravana Kumar, E., Vengatesan, K. Trust based resource selection with optimization technique. Cluster Comput 22, 207-213 (2019)

16. S. Zhang, D. Zhang, H. Zhong and G. Wang, "A Multiclassification Model of Sentiment for ECommerce Reviews," in IEEE Access, vol. 8, pp. 189513-189526, 2020.doi: 10.1109/ACCESS.2020.3031588.

17. S. Aloufi and A. E. Saddik, "Sentiment Identification in Football-Specific Tweets," in IEEE Access, vol. 6, pp. 78609-78621, 2018.doi: 10.1109/ACCESS.2018.2885117. 
18. D. Deng, L. Jing, J. Yu, S. Sun and M. K. Ng, "Sentiment Lexicon Construction With Hierarchical Supervision Topic Model," in IEEE/ACM Transactions on Audio, Speech, and Language Processing, vol. 27, no. 4, pp. 704-718, April 2019.doi: 10.1109/TASLP.2019.2892232.

19. Z. Hai, G. Cong, K. Chang, P. Cheng and C. Miao, "Analyzing Sentiments in One Go: A Supervised Joint Topic Modeling Approach," in IEEE Transactions on Knowledge and Data Engineering, vol. 29, no. 6, pp. 1172-1185, 1 June 2017.doi: 10.1109/TKDE.2017.2669027.

20. N. Al-Twairesh and H. Al-Negheimish, "Surface and Deep Features Ensemble for Sentiment Analysis of Arabic Tweets," in IEEE Access, vol. 7, pp. 84122-84131, 2019.doi: 10.1109/ACCESS.2019.2924314.

21. Z. Ren, G. Zeng, L. Chen, Q. Zhang, C. Zhang and D. Pan, "A Lexicon-Enhanced Attention Network for Aspect-Level Sentiment Analysis," in IEEE Access, vol. 8, pp. 93464-93471, 2020.doi: 10.1109/ACCESS.2020.2995211.

22. C. R. Aydin and T. Güngör, "Combination of Recursive and Recurrent Neural Networks for AspectBased Sentiment Analysis Using Inter-Aspect Relations," in IEEE Access, vol. 8, pp. 77820-77832, 2020.doi: 10.1109/ACCESS.2020.2990306.

23. Y. Fang, H. Tan and J. Zhang, "Multi-Strategy Sentiment Analysis of Consumer Reviews Based on Semantic Fuzziness," in IEEE Access, vol. 6, pp. 20625-20631, 2018.doi: 10.1109/ACCESS.2018.2820025.

24. D. She, J. Yang, M. Cheng, Y. Lai, P. L. Rosin and L. Wang, "WSCNet: Weakly Supervised Coupled Networks for Visual Sentiment Classification and Detection," in IEEE Transactions on Multimedia, vol. 22, no. 5, pp. 1358-1371, May 2020.doi: 10.1109/TMM.2019.2939744.

25. X. Fu, J. Yang, J. Li, M. Fang and H. Wang, "Lexicon-Enhanced LSTM With Attention for General Sentiment Analysis," in IEEE Access, vol. 6, pp. 71884-71891, 2018.doi: 10.1109/ACCESS.2018.2878425.

26. Z. Cui, Q. Qiu, C. Yin, J. Yu, Z. Wu and A. Deng, "A Barrage Sentiment Analysis Scheme Based on Expression and Tone," in IEEE Access, vol. 7, pp. 180324-180335, 2019.doi: 10.1109/ACCESS.2019.2957279.

27. Abhishek Kumar, K. Vengatesan, Ashutosh Srivastava, Achintya Singhal, Sayyad Samee, V D Ambeth Kumar. (2020). An Approach of Comparative Investigation of Classification Algorithm for Prediction of Google App . International Journal of Control and Automation, 13(4), 958 - 974

28. E. Zuo, H. Zhao, B. Chen and Q. Chen, "Context-Specific Heterogeneous Graph Convolutional Network for Implicit Sentiment Analysis," in IEEE Access, vol. 8, pp. 37967-37975, 2020.doi: 10.1109/ACCESS.2020.2975244.

29. J. Zhou, S. Jin and X. Huang, "ADeCNN: An Improved Model for Aspect-Level Sentiment Analysis Based on Deformable CNN and Attention," in IEEE Access, vol. 8, pp. 132970-132979, 2020.doi: 10.1109/ACCESS.2020.3010802.

30. J. Yu, J. Jiang and R. Xia, "Entity-Sensitive Attention and Fusion Network for Entity-Level Multimodal Sentiment Classification," in IEEE/ACM Transactions on Audio, Speech, and Language Processing, vol. 28, pp. 429-439, 2020.doi: 10.1109/TASLP.2019.2957872.

31. Z. Kastrati, A. S. Imran and A. Kurti, "Weakly Supervised Framework for Aspect-Based Sentiment Analysis on Students' Reviews of MOOCs," in IEEE Access, vol. 8, pp. 106799-106810, 2020.doi: 10.1109/ACCESS.2020.3000739.

32. S. Hu, A. Kumar, F. Al-Turjman, S. Gupta, S. Seth and Shubham, "Reviewer Credibility and Sentiment Analysis Based User Profile Modelling for Online Product Recommendation," in IEEE Access, vol. 8, pp. 26172-26189, 2020.doi: 10.1109/ACCESS.2020.2971087. 